\title{
PREDIKSI KADAR AIR BUBUK BIJI KAKAO MENGGUNAKAN NIRS DENGAN METODE PLS
}

\author{
(Dengan Pre-Treatment Derivative Ke-1 dan Mean Centering) \\ (PREDICTION OF WATER LEVEL OF POWDER COCOA BEANS WITH USING NIRS PLS \\ (With Pre-Treatment Derivative Ke-1 and Mean Centering)
}

\section{Cut Multin Ulva*, Zulfahrizal, Agus Arip Munawar}

Program Studi Teknik Pertanian, Fakultas Pertanian, Universitas Syiah Kuala

\begin{abstract}
Abstrak. Mayoritas biji kakao Indonesia dianggap bermutu rendah. Salah satu metode yang saat ini sedang berkembang dan digunakan untuk mendeteksi kualitas suatu produk pertanian adalah metode Near Infrared Reflectance Spectroscopy (NIRS). Penelitian ini menggunakan sampel biji kakao varietas lindak yang didapat dari petani kemudian dijadikan dalam bentuk bubuk untuk di prediksi kadar airnya menggunakan NIRS dengan metode Partial Least Squares (PLS) sebagai metode regresi serta membandingkan antara pretreatment Derivative 1 (D1) dan Mean Centering (MC) sebagai metode koreksi. Hasil penelitian ini didapat bahwa panjang gelombang 1860-2000 merupakan panjang gelombang yang relevan dalam menduga kadar air pada bubuk biji kakao. Mean Centering adalah pretreatment terbaik diantara dua macam pretreatment yang dipakai dalam penelitian ini.
\end{abstract}

Kata kunci : Kakao, Kadar air, Near Infrared Reflectance Spectroscopy.

Abstract. The majority of Indonesia kakao is considered to have a low grade. One of the development method that is used to detect the quality of a product is NIRS Method. This research used the lindak variety of kakao beans tha obtained from local farmer then processed in a powder from to predict the water content by using NIRS with PLS as regresion methot also to compare between spektra method nermely pretreatment derivative 1(D1) and MC. From the result of the research is obtained the wavelength range 1860-2000 is the relevant wavelength in predicting the water content in cocoa powder. Mean Centering fond to be the best pretreatment that is used in this research.

Keywords: Cocoa, the water level, near infrared reflectance spectroscopy .

\section{PENDAHULUAN}

Kakao (Theobroma cacao L.) merupakan salah satu komoditas ekspor yang dapat memberikan kontribusi untuk peningkatan devisa negara. Indonesia merupakan salah satu negara pembudidaya tanaman kakao yang luas di dunia. Indonesia berdasarkan data ICCO (International Cocoa Organization) merupakan produsen biji kakao nomor tiga dunia setelah Pantai Gading dan Ghana. Mayoritas biji kakao Indonesia dianggap bermutu rendah. Beberapa faktor penyebab mutu kakao beragam yang dihasilkan adalah minimnya sarana pengolahan, lemahnya pengawasan mutu serta penerapan teknologi pada seluruh tahapan proses pengolahan biji kakao rakyat yang tidak berorientasi pada mutu. Hal ini tercermin dari harga kakao Indonesia yang relatif rendah dan dikenakan potongan harga dibandingkan dengan produk yang sama dari negara produsen lain.

SNI menetapkan standar mutu biji kakao dilihat secara fisik seperti kadar air, kontaminasi terhadap serangga, benda asing dan berbagai aroma yang dapat merusak aroma khas kakao (BSN, 2008). Kadar air merupakan banyaknya air yang terkandung dalam bahan yang dinyatakan dalam persentase tertentu. Banyaknya kandungan kadar air di dalam bubuk biji kakao dapat mempengaruhi penampakan, tekstur dan cita rasa. Kadar air di dalam bahan itu sendiri ikut menentukan daya awet bahan pangan tersebut, kadar air yang tinggi mengakibatkan mudahnya bakteri, kapang, dan khamir untuk berkembang biak sehingga terjadi 
perubahan pada bahan. Namun bila kadar air terlalu rendah $(<6 \%)$ biji akan mudah patah dan pecah.

Pendugaan mutu kakao biasanya dilakukan melalui uji laboratorium (secara destruktif), dimana biji kakao dihancurkan dan diambil sarinya yang kemudian dianalisis dengan metode standar kimia yang umum di laboratorium. Faktanya, metode ini menghabiskan waktu yang cukup lama dan mahal, sehingga diperlukan solusi untuk pendugaann mutu kakao yang lebih cepat dan tidak merusak bahan (non-destruktif).

Salah satu metode yang saat ini sedang berkembang dan digunakan untuk mendeteksi kualitas suatu produk pertanian adalah metode pantulan infra merah dekat atau Near Infrared Reflectance Spectroscopy (NIRS). Metode ini dapat menganalisis kualitas produk pertanian dengan waktu yang sangat cepat dan dilakukan secara nondestruktif atau tanpa merusak buah bahkan tanpa menyentuh produk tersebut.

\section{METODE PENELITIAN}

Penelitian telah dilaksanakan pada Bulan Maret sampai Mei 2016 dilakukan di Laboratorium Instrumentasi, dan Energi, Program Studi Teknik Pertanian, Fakultas Petanian, Universitas Syiah Kuala, Banda Aceh.

\section{Alat dan Bahan}

Alat yang digunakan pada penelitian ini adalah FT-IR IPTEK T-1516, perlengkapan uji kadar air, perlengkapan pembubukan biji kakao dan unscrambler software ${ }^{\circledR} X$ version 10.1 . Bahan yang digunakan pada penelitian ini adalah biji kakao.

\section{Metode Penelitian}

Penelitian ini menggunakan buah kakao varietas lindak yang didapat dari Jember berupa yang non fermentasi dan difermentasi. Kemudian kakao tersebut disimpan selama 3 hari di ruangan dengan suhu $25^{\circ} \mathrm{C}$ yang bertujuan untuk menstabilkan suhu pada biji kakao. Selanjutnya dilakukan penghancuran pada biji kakao dengan menggunakan alat penghancur (blender) dan dihasilkan bubuk kasar. Selanjutnya diayak dengan ayakan berukuran 24 mesh untuk mendapatkan bubuk kakao yang halus dengan ukuran yang seragam. Jumlah sampel sebanyak 30 sampel yang terdiri dari 15 sampel non fermentasi dan 15 sampel yang difermentasi.

\section{Pengambilan Spektrum Bubuk Biji Kakao}

Kemudian dilakukan pengambilan spektrum pada bubuk biji kakao dengan menggunakan alat NIRS FT-IR IPTEK T-1516 tiap jam. Kalibrasi background/reference dilakukan tiap jam. Proses pengukurannya menggunakan integrating sphere. Alat dikendalikan dengan 2 workflow dan menjalankan workflow menggunakan software termo intregation ${ }^{\circledR}$ dan untuk running alat dilakukan oleh termo operation $\AA$. Selang panjang gelombang yang dipilih adalah antara 1000$2500 \mathrm{~nm}$ dengan interval $0.4 \mathrm{~nm}$. Workflow dibuat untuk mengatur alat agar bekerja untuk mengakuisisi spektrum absorban, memindai sampel sebanyak 64 kali perproses lalu merataratakan hasilnya, menyimpan hasil pemindaian dalam 3 bentuk file yakni *.SPA. *.JDX dan *.CSV. Akuisisi Spektrum biji kakao dilakukan dalam bentuk biji kakao yang dibubukkan. Pengambilan spektrumnya dengan cara memasukkan bubuk kedalam petridish yang tersedia lalu diputar 360 derajat selama proses pemindaian sampel. Data absorban diperoleh dengan cara menstransformasikan nilai reflektan/pantulan kedalam bentuk Log (1/R). Pretreatment yang digunakan adalah Derivative ke $1(D 1)$ dan Mean Centering (MC). Model prediksi dibangun dengan metode Partial Least Squares (PLS) untuk menduga kadar air bubuk biji kakao. 


\section{Prosedur Pengujian di Laboratorium}

Pengujian kadar air menggunakan adalah metode thermogravimetri. Prosedur pengukuran adalah cawan keramik kosong dikeringkan dalam oven dengan suhu $105^{\circ} \mathrm{C}$ selama 15 menit dan didinginkan dalam exicator selama 10 menit, kemudian ditimbang. Sampel yang sudah diambil data spektranya ditimbang 2-3 gram kemudian dimasukkan ke dalam cawan. Cawan beserta isinya kemudian dimasukkan ke dalam oven dengan suhu $105^{\circ} \mathrm{C}$ selama 6 jam. Selanjutnya cawan dikeluarkan dari oven dan didinginkan kembali dalam exicator dan ditimbang kembali. Perhitungan kadar air (KA) menggunakan persamaan :

$$
\mathrm{KA}=\frac{\mathrm{B} 1-\mathrm{B} 2}{\mathrm{~B} 1} \times 100 \%
$$

Keterangan :

$$
\mathrm{KA}=(\% \text { basis basah }) \mathrm{B}_{1}=\text { Berat awal } \quad \mathrm{B}_{2}=\text { Berat akhir }
$$

\section{Pengembangan Model Kalibrasi dan Validasi Kadar Air dalam Bubuk Biji Kakao}

Keseluruhan data dipakai sebagai dataset kalibrasi yang digunakan untuk membangun model prediksi kadar air. Kemudian dilakukan validasi silang ( $K$-fold cross validation) dengan jumlah segment (fold) adalah 10. Model prediksi dibangun dengan menggunakan metode Partial Least Squares (PLS) yang dibandigkan dengan hasil uji laboratorium.

Evaluasi keakuratan dan kehandalan model dievaluasi dengan melihat parameter statistik yang meliputi: koefisien kolerasi $(\mathrm{r})$, koefesien determinasi $\left(\mathrm{R}^{2}\right)$, residual predictive deviation (RPD) index, root mean square error cross validation (RMSECV), root mean square error calibration (RMSEC), latent variable (LV), dan dRMSE . Model persamaan kalibrasi data serapan dibandingkan dengan data aktual dan dilihat nilai r, RMSEC, RMSECV, RPD, dan LV. Model yang bagus memiliki nilai $r$ dan $\mathrm{R}^{2}$ yang tinggi, RMSEC yang rendah, RPD > 1.5 jumlah latent variable $<9$; RMSEC, RPD, dan dRMSE dicari dengan persamaan (Florez, 2009 ; Jha, 2006 ; Nicolai, 2007 ; Zulfahrizal, 2015) :

$$
\begin{aligned}
& \mathrm{dRMSE}=|R M S E C V-R M S E C| \ldots \ldots \ldots \ldots . \\
& R M S E C, R M S E C V=\sqrt{\frac{1}{n} \sum_{i=1}^{n}\left(\hat{y}_{i}-y_{i}\right)} . \\
& R P D=\frac{S D}{R M S E C V} \ldots \ldots \ldots \ldots \ldots \ldots \ldots \ldots \ldots \ldots \ldots \ldots \ldots \ldots \ldots \ldots \ldots
\end{aligned}
$$

Dimana : $\hat{y}_{I}=$ parameter nilai dari dugaan awal model sampel ke-i.

$\mathrm{y}_{\mathrm{i}}=$ parameter nilai hasil pengukuran laboratorium untuk sampel ke-i

$\mathrm{n}=$ jumlah sampel dalam kalibrasi atau validasi.

$\mathrm{SD}=$ standar deviasi untuk data aktual.

\section{HASIL DAN PEMBAHASAN Typical Spektrum NIRS Bubuk Biji Kakao}

Spektrum original atau disebut juga raw spektrum merupakan hasil pengambilan spektrum NIRS pada selang panjang gelombang 1000-2500 nm dengan interval $0.4 \mathrm{~nm}$. Jumlah sampel yang digunakan adalah sebanyak 30 sampel bubuk biji kakao. Selang panjang gelombang dibawah $1000 \mathrm{~nm}$ sengaja dipotong karena cenderung tidak memberikan informasi yang dibutuhkan untuk pengukuran spektra dengan alat NIRS. Gambar 1. memaparkan spektrum NIRS untuk bubuk biji kakao sebanyak 30 sampel. 


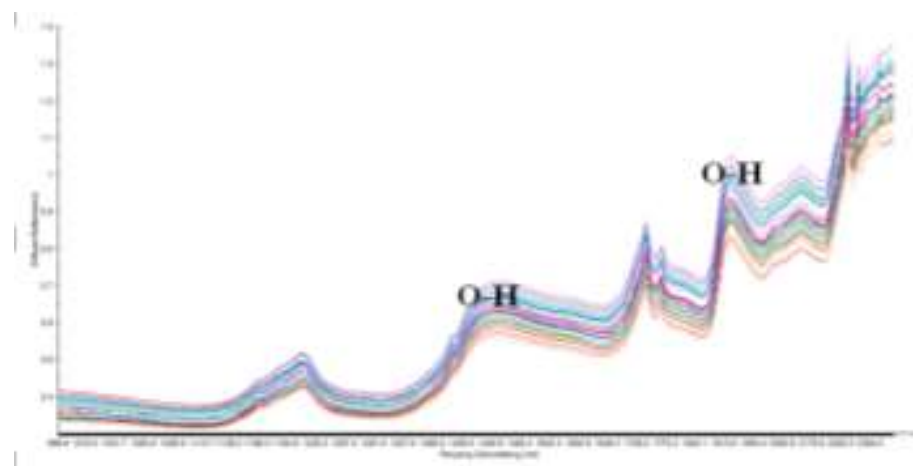

Gambar 1. Spektrum NIRS pada Bubuk Biji Kakao

\section{Perbaikan Spektrum dengan metode Derivative ke-1}

Kandungan kadar air untuk Pretreatment derivative 1 yaitu panjang gelombang yang menghasilkan getaran ikatan $\mathrm{H}_{2} \mathrm{O}$ adalah $1360-1430$ untuk puncak yang pertama, dan 18801970 untuk puncak kedua. Panjang gelombang 1880-1970 adalah panjang gelombang yang relevan penanda keberadaan kadar air mengingat pada panjang gelombang tersebut terjadi overton kedua (Gambar 2).

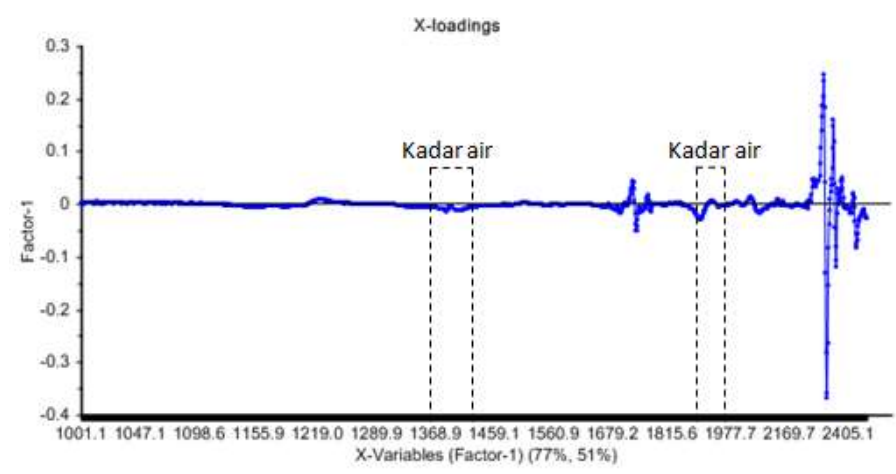

Gambar 2. Loading Plot untuk Pretreatment D1

\section{Perbaikan Spektrum dengan metode Mean Centering}

Getaran yang terjadi pada panjang gelombang adalah 1370-1490, dan 1860-1970 nm menunjukkan adanya ikatan O-H (penanda keberadaan kadar air). Panjang gelombang 18601970 adalah panjang gelombang yang relevan penanda keberadaan kadar air mengingat pada panjang gelombang tersebut terjadi overton kedua (Gambar 3).

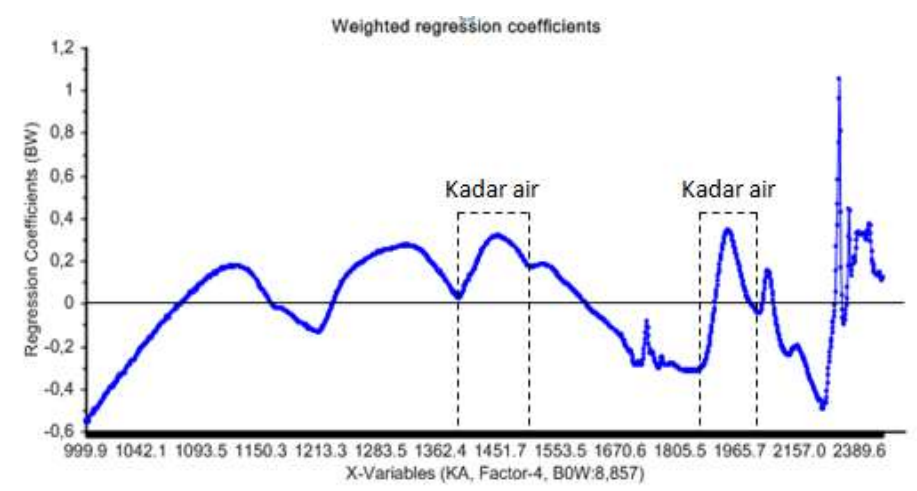

Gambar 3. Loadings Plot untuk Pretreatment MC 


\subsection{Pengaturan Data Kalibrasi}

Pengaturan kalibrasi berisi 30 sampel bubuk biji kakao. Selanjutnya dibuat acuan pengukuran untuk sampel kalibrasi seperti selang antar sampel, rataannya dan standar deviasi sampel untuk pengukuran kadar air yang dapat dilihat pada Tabel 1.

Tabel 1. Acuan Pengukuran Pengaturan Data Kalibrasi

\begin{tabular}{lcccc}
\hline Bagian & Jumlah & \multicolumn{3}{c}{ Kadar Air } \\
\cline { 3 - 5 } & Data & Selang (\%) & Rataan & Standar Deviasi \\
\hline Kalibrasi & 30 & $7.42-11.09$ & 8.85 & 0.9353 \\
\hline
\end{tabular}

\subsection{Pengembangan Model Kalibrasi (Partial Least Squares)}

Kalibrasi digunakan untuk membangun model persamaan matematik yang dapat digunakan untuk memprediksi kandungan kimia buah tanpa harus melakukan pengukuran langsung yang merusak bahan. Bubuk biji kakao yang digunakan pada penelitian ini memiliki selang kadar air antara $7.42 \%-11.09 \%$ yang diperoleh dari hasil analisis laboratorium. Nilai kadar air sangat mempengaruhi daya tahan kakao untuk penyimpanan serta daya tahan terhadap serangan jamur dan mikroba. Standar deviasi kadar air yang didapat sebesar 0.9353. Hasil analisa kalibrasi PLS untuk uji kadar air menggunakan NIRS dengan beberapa perlakuan pretreatment pada bubuk biji kakao dapat dilihat pada Tabel 2.

Tabel 2. Hasil Kalibrasi kadar Air Bubuk Biji kakao

\begin{tabular}{lcccc}
\hline $\begin{array}{l}\text { Perlakuan } \\
(\%)\end{array}$ & Latent variable & $\mathrm{R}^{2}$ & $\mathrm{r}$ & $\mathrm{RMSEC}$ \\
\hline Non pretreatment & 4 & & & \\
Derivative 1 & 3 & 0.75 & 0.87 & 0.45 \\
Mean centering & 4 & 0.73 & 0.86 & 0.46 \\
\hline
\end{tabular}

Hasil pendugaan pada tahap kalibrasi untuk PLS non pretreatment memperlihatkan nilai koefisien korelasi ( $\mathrm{r}$ ) sebesar 0,87, koefisien determinasi $\left(\mathrm{R}^{2}\right)$ sebesar 0,75 Menurut Karoui et al. (2006), nilai $\mathrm{R}^{2}$ berkisar 0,66 - 0,81 menunjukkan dugaan yang mendekati prediksi kuantitatif. Sementara nilai error (RMSEC) yang masih di bawah nilai SD data yaitu 0,45 serta nilai latent variable yaitu 4. Plot data kalibrasi non pretreatment dapat dilihat pada Gambar 4.

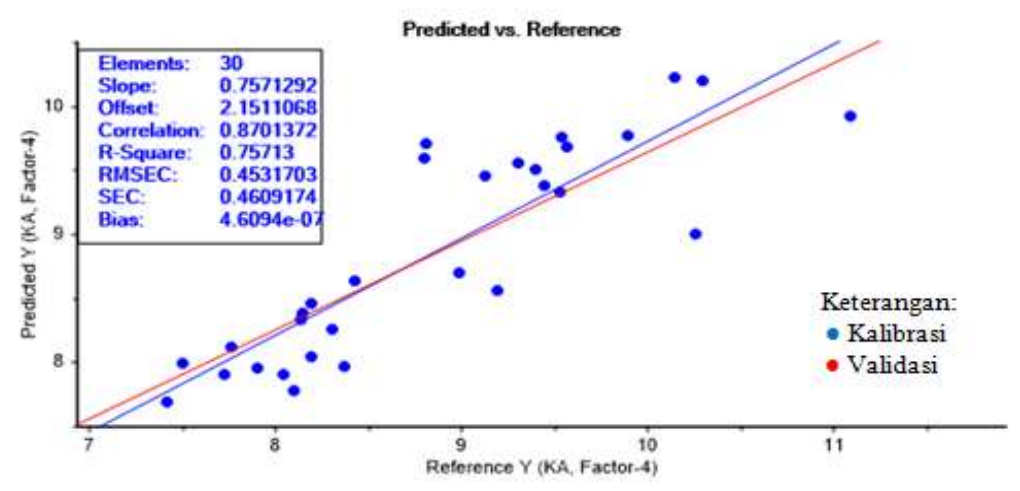

Gambar 4. Plot Data Kalibrasi Kadar Air Non Pretreatment

Prediksi Kadar Air Bubuk Biji Kakao Menggunakan Nirs Dengan Metode PLS

(Dengan Pre-Treatment Derivative Ke-1 dan Mean Centering) (Cut Multin Ulva, Zulfahrizal, 
Hasil pendugaan pada tahap kalibrasi untuk PLS Derivative $k e-1$ memperlihatkan nilai koefisien korelasi (r) sebesar 0,86, koefisien determinasi $\left(\mathrm{R}^{2}\right)$ sebesar 0,73 menunjukkan dugaan yang mendekati prediksi kuantitatif. Sementara nilai error (RMSEC) yang masih di bawah nilai SD data yaitu 0,46 serta nilai latent variable yaitu 3. Plot data kalibrasi untuk PLS Drivative ke-1 dapat dilihat pada Gambar 5.

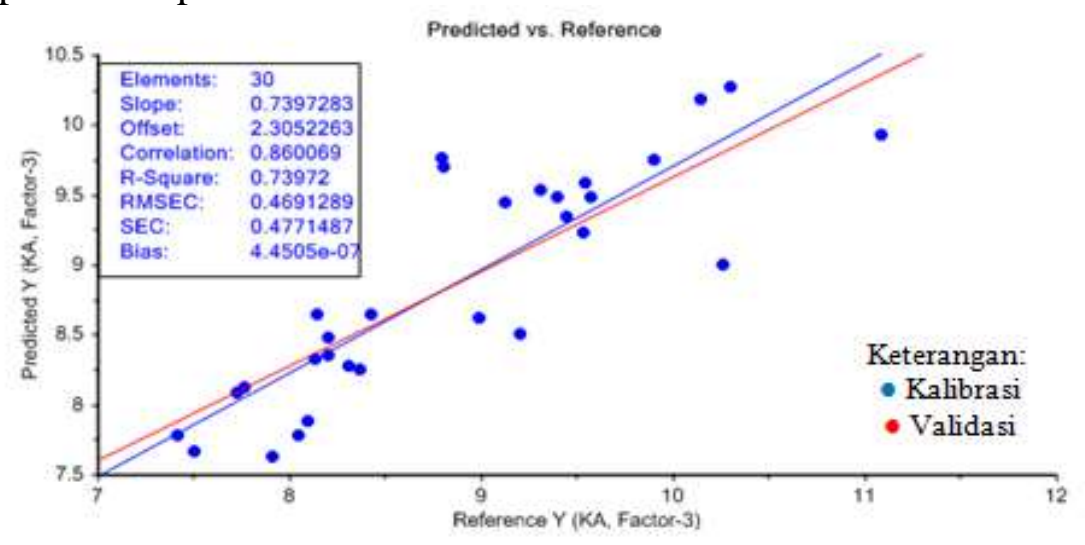

Gambar 5. Plot Data Kalibrasi Kadar Air D1 + PLS

Hasil pendugaan pada tahap kalibrasi untuk PLS Mean Centering memperlihatkan nilai koefisien korelasi (r) sebesar 0,87, koefisien determinasi $\left(\mathrm{R}^{2}\right)$ sebesar 0,75 menunjukkan dugaan yang mendekati prediksi kuantitatif. Sementara nilai error (RMSEC) yang masih di bawah nilai SD data yaitu 0,45 serta nilai latent variable yaitu 4. Plot data kalibrasi untuk PLS Mean Centering dapat dilihat pada Gambar 6.

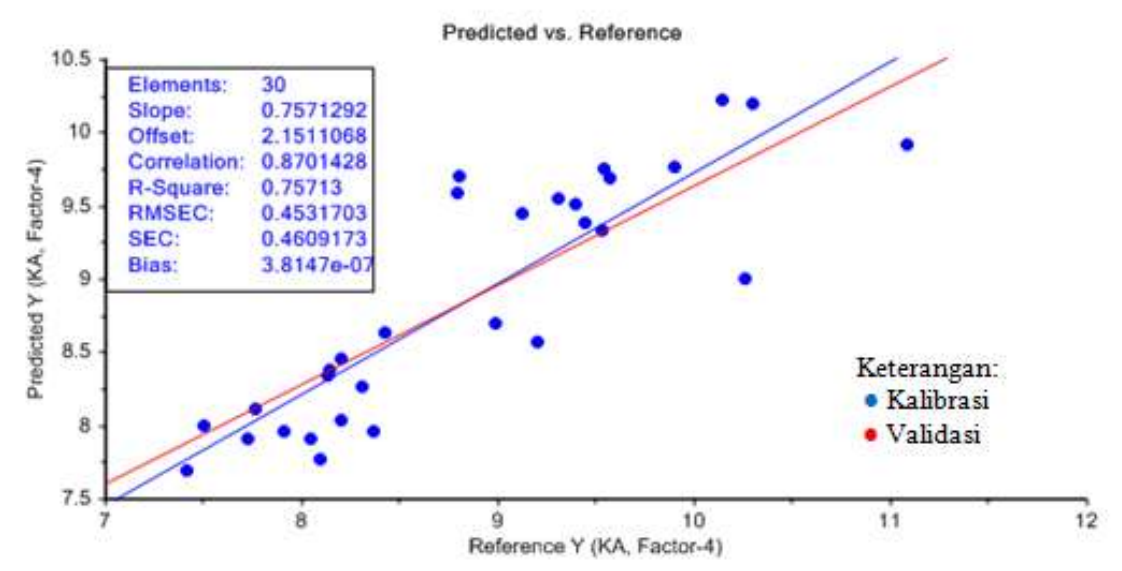

Gambar 6. Plot Data Kalibrasi Kadar Air MC + PLS

\subsection{Validasi / Pengujian Model Kalibrasi}

Cross Validation yaitu suatu teknik untuk menilai/memvalidasi keakuratan sebuah model yang dibangun berdasarkan dataset tertentu. Pada penelitian ini dipakai $k$-fold cross validation yaitu suatu teknik dimana dataset dibagi menjadi sejumlah segment k-buah partisi secara acak. Kemudian dilakukan sejumlah segment k-kali. Sampel yang digunakan adalah 30 sampel yang dibagi menjadi 10 segment dan sampel per segment adalah 3. Hasil Cross Validasi dapat dilihat pada tabel 3 . 
Tabel 3. Hasil Validasi kadar Air Bubuk Biji kakao

\begin{tabular}{lccccc}
\hline Perlakuan & $\mathrm{R}^{2}$ & $\mathrm{r}$ & RMSECV $(\%)$ & dRMSE & RPD \\
\hline Non pretreatment & 0.67 & 0.80 & 0.54 & 0.09 & 1.73 \\
Derivative 1 & 0.65 & 0.79 & 0.55 & 0.09 & 1.70 \\
Mean Centering & 0.67 & 0.80 & 0.54 & 0.09 & 1.73 \\
\hline
\end{tabular}

Keakuratan model validasi ditentukan berdasarkan nilai $\mathrm{R}^{2}$, error dan RPD. Pada perlakuan non pretreatment nilai $\mathrm{R}^{2}$ yang didapat adalah 0.67 menunjukkan dugaan yang mendekati prediksi kuantitatif. Sedangkan nilai r yang didapat cukup besar yakni 0.80 . Untuk nilai error (RMSECV) yang didapat 0.54 , masih dikatakan baik karena masih di bawah nilai SD data. Nilai dRMSE yang bagus yaitu sebesar 0.09. Selanjutnya jika dilihat dari nilai RPD, ternyata didapat nilai 1.73. Menurut Nicolai et al. (2007) nilai RPD yang berada dalam selang 1.5 - 2 menandakan bahwa model itu termasuk sufficient performance yang dapat dikatakan prediksi kuantitatif kasar yang dianggap mungkin (Gambar 7).

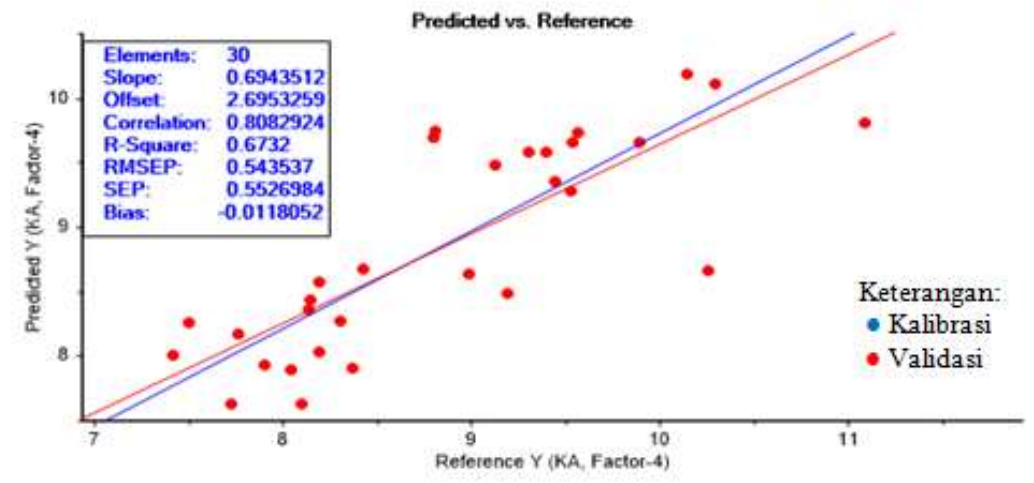

Gambar 7. Plot Data Validasi Kadar Air Non Pretreatmen

Pemakaian pretreatmen Derivative ke-1 nilai $\mathrm{R}^{2}$ yang didapat adalah 0.65 . Sedangkan nilai r yang didapat cukup besar yakni 0.79. Untuk nilai error (RMSECV) yang didapat sebesar 0.55 , masih dikatakan baik karena masih di bawah nilai SD data. Nilai dRMSE yang bagus yaitu sebesar 0.09. Selanjutnya jika dilihat dari nilai RPD, ternyata didapat nilai 1.70 model itu termasuk sufficient performance yang dapat dikatakan prediksi kuantitatif kasar yang dianggap mungkin (Gambar 8). 


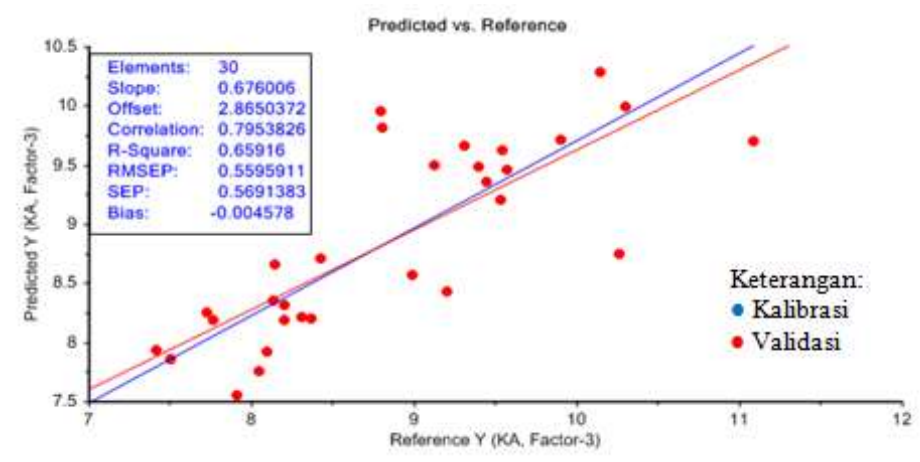

Gambar 8. Plot Data Validasi Kadar Air D1 + PLS

Pemakaian pretreatment mean centering nilai $\mathrm{R}^{2}$ yang didapat adalah 0.67 menunjukkan dugaan yang mendekati prediksi kuantitatif. Sedangkan nilai $r$ yang didapat cukup besar yakni 0.80 . Untuk nilai error (RMSECV) yang didapat 0.54 , masih dikatakan baik karena masih di bawah nilai SD data. Nilai dRMSE yang bagus yaitu sebesar 0.09. Selanjutnya jika dilihat dari nilai RPD, ternyata didapat nilai 1.73 model itu termasuk sufficient performance yang dapat dikatakan prediksi kuantitatif kasar yang dianggap mungkin (Gambar 9).

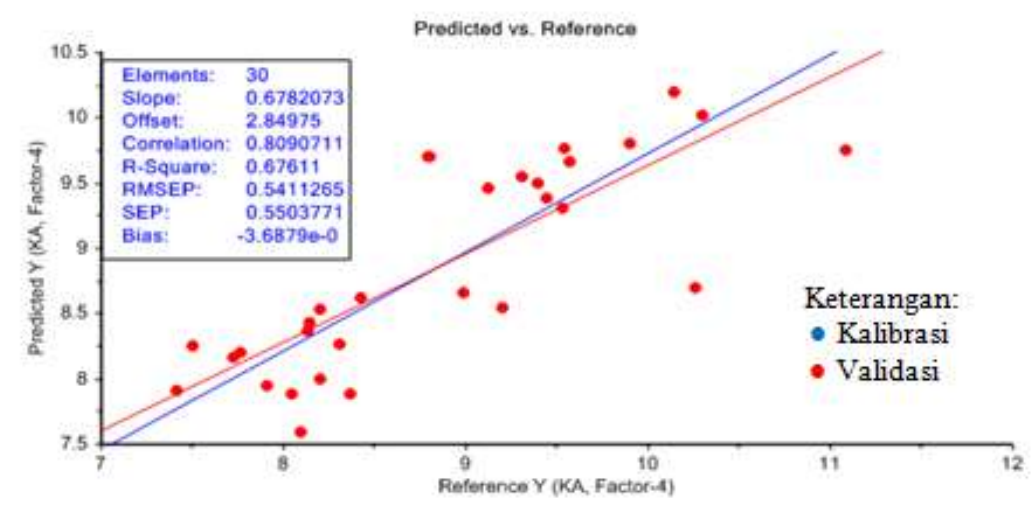

Gambar 9. Plot Data Validasi Kadar Air MC+ PLS

Kemampuan PLS dalam menduga kadar air pada bubuk biji kakao dapat dikatakan bagus dilihat dari hasil cross validasi. PLS tanpa pretreatment masih menghasilkan model yang tergolong sufficient performance. walaupun nilai $r$ hasil cross validasi berkurang $8,04 \%$ dari kalibrasi, nilai dRMSE sebesar 0,09 serta nilai RPD 1.73.

PLS dengan penambahan derivative ke 1 menghasilkan model yang tergolong sufficient performance walaupun nilai $r$ hasil cross validasi berkurang sebesar $8.13 \%$ dari kalibrasi, nilai dRMSE sebesar 0,09 dan nilai RPD yaitu 1,70. Selanjutnya PLS dengan penambahan mean centering nilai $\mathrm{r}$ hasil cross validasi berkurang sebesar $8.04 \%$, serta nilai dRMSE berkurang sebesar 0.09 dan nilai RPD yaitu 1,73. Akan tetapi jika ingin dibandingkan diantara 2 pretreatment yang dipakai maka dapat disimpulkan pretreatment Mean Centering lebih baik dari pretreatment Derivative ke-1, dilihat dari persentase nilai $\mathrm{r}$ hasil cross validasi mean centering yang berkurang paling kecil yaitu sebesar $8.04 \%$ dari kalibrasi, nilai $\mathrm{R}^{2}$ yaitu masih dugaan yang mendekati prediksi kuantitatif. Nilai error (RMSECV) yang masih dikatakan baik karena masih di bawah nilai SD data. dan nilai RPD yang tergolong sufficient performance. Namun penggunaan pretreatmen pada penelitian ini tidak mampu meningkatkan kinerja PLS hal ini dilihat dari nilai r, $\mathrm{R}^{2}$, RPD yang tidak meningkat dibanding Non Pretreatmen dan nilai error yang tidak menurun. 


\section{KESIMPULAN DAN SARAN}

Kesimpulan dari penelitian ini yaitu Panjang gelombang 1860-2000 nm merupakan panjang gelombang yang paling relevan dalam menduga kadar air pada bubuk biji kakao. Metode NIRS menggunakan PLS dapat digunakan untuk menduga kandungan kadar air bubuk biji kakao dalam jumlah 10 gram dengan selang kadar air 7.42\% - 11.09\%.Pendugaan kadar air dengan PLS tanpa pretreatmen telah menghasilkan model sufficient performance. Penggunaan pretreatment (derivative 1 dan mean centering) pada penelitian ini yang dianggap baik kinerjanya adalah mean centering akan tetapi keduanya tidak meningkatkan kinerja PLS. Untuk sarannya yaitu Perlu dilakukan penelitian lebih lanjut dengan menggunakan metode pretreatment yang lain seperti De-Trending (DT), Mean Normalization (MN), serta membangun model prediksi dengan metode linier (PCR, SMLR) dan non linier (SVMR, ANN).

\section{DAFTAR PUSTAKA}

[BSN] Badan Standarisasi Nasional. (2008 ${ }^{\mathrm{a}}$. Parameter Mutu dan Pengukuran Standarisasi Kakao dan Kopi.

[BSN] $\left(2009^{b}\right)$. Standar nasional indonesia bubuk kakao. SNI 3747. 2009.Badan Standardisasi Nasional.

Karoui R., A. M. Mouazena, E. Dufourb, L. Pillonelc, E. Schallerd, J. De Baerdemaekera, Dan J. O. Bossetc. 2006. Chemical Characterisation Of European Emmental Cheeses By Near Infrared Spectroscopy Using Chemometric Tools. International Dairy Journal. 16: 12111217.

Munawar, A. A. 2008. Non-Destructive Inner Quality Prediction in Intact Mangos with NIRS Method. Thesis. George-August University, Goettingen.

Munawar, A. A. 2014. Multvariate Analysis and Artificial Neural Network Appoaches of Near Infrared Spectroscopic Data for Non-Destructive Quality Atributes Prediction of Mango. Disertasi. Georg-August University, Goettingen.

Munawar, A. A. 2015. Rapid Classification of Agricultural Products Based on Their ElectroOptic Properties Using Near Infrared Reflectance and Chemometrics. J. Rona Teknik Pertanian ISSN : 2085-2614

Nicolai, B. M., K. Beullens, E. Bobelyn, A. Peirs, W. Saeys, K. I. Theron, J. Lamertyn. 2007. Nondestructive Measurement of Fruit and Vegetable Quality by Means of NIR Spectroscopy : A Review. Postharvest Biology and Technology. 46: 99-118.

Zulfahrizal. 2014. Pengembangan Metode Pengukuran Nondestruktif untuk Menentukan Mutu dan Fermentasi Biji Kakao Utuh Menggunakan NIR Spectroscopy. Disertasi. Institut Pertanian Bogor . Bogor .

Zulfahrizal, Sutrisno, I W. Budiastra, K. B. Seminar, A. A. Munawar. 2013. Akuisisi Spektrum Near Infrared Reflectance pada Biji Kakao. Bul. Riset Tanaman Rempah dan Aneka Tanaman Industri, 4, 1-10.

Zulfahrizal, A. A. Munawar, dan H. Meilina. 2015 . Estimasi Kandungan Lemak pada Biji Kakao Utuh Secara Cepat dan Non-Destruktif dengan Menggunakan Teknologi NIRS. Seminar Nasional Instrumentasi, Kontrol dan Otomatis (SNIKO) Bandung Indonesia. 1011 Desember.

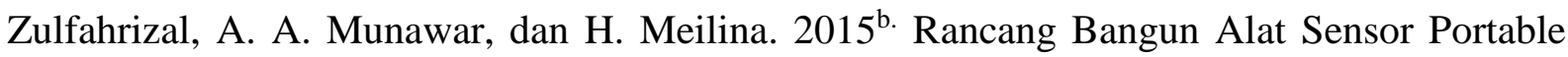
Berbasis Pengembangan Aplikasi Teknologi Near Infrared sebagai Metode Baru yang Rapid dan Non-Destruktif untuk Prediksi Kualitas Kakao. Laporan Penelitian Pengembangan Ilmu Pengetahuan dan Teknologi. Universitas Syiah Kuala. 